http://www.jfas.info

\title{
THE RELATIONSHIP BETWEEN EMPOWERMENT AND EFFECTIVENESS OF STAFF (CASE STUDY: NATIONAL BANK STAFF IN GUILAN PROVINCE)
}

\author{
A. A. Louyeh $^{1}$, P. Ebrahimi ${ }^{2}$, A. G. Soleimani ${ }^{2}$, A. Shadmehr ${ }^{3}$ \\ ${ }^{1}$ Department of nursing, School of nursing and midwifery, Guilan University of medical \\ sciences, Rasht, Iran \\ ${ }^{2}$ Department of Management, Rasht Branch, Islamic Azad University, Rasht, Iran \\ ${ }^{3}$ Department of Management, Qazvin Branch, Islamic Azad University, Qazvin, Iran
}

Published online: 16 July 2016

\begin{abstract}
Effectiveness is one of the management concepts considered and studied always by management scientists and experts. The aim of this study was to investigate the effects of different dimensions of empowerment (servicing staff, staff monitoring, consulting staff, and training staff) on dimensions of effectiveness of staff (staff satisfaction and staff performance). This study is applied in terms of data collection and it is survey type of descriptive study in terms of data collection. The study population includes staff of National Bank branches in Guilan province, that their number is 1397 people. Cochran formula was used to determine sample size of study and 302 people were selected as minimum sample of study. Simple random sampling was used as method of sampling. Fir increased confidence, 360 questionnaires were distributed that 315 questionnaires were returned and analyzed. Method of data collection is using questionnaire distributed among samples of study after its validity and reliability were confirmed.
\end{abstract}

Author Correspondence, e-mail: pejman.ebrahimi77@gmail.com doi: http://dx.doi.org/10.4314/jfas.v8i2s.30 
SPSS software was used to analyze the data in descriptive statistics section and structural equation modeling using AMOS software was used in the inferential statistics using AMOS software to test the hypotheses of study. The results showed there is significant positive correlation between different dimensions of empowerment and dimensions of effectiveness of staff.

Keywords: staff effectiveness, staff empowerment, staff training, staff performance, staff satisfaction

\section{INTRODUCTION}

The effectiveness is one of the management concepts considered and studied always by management scientists and experts. There is a direct relationship between staff empowerment and organizational effectiveness, as a staff with high power in a dynamic organization has more efficiency than staff with low power. To achieve these features, organizations should empower the most important source of its competitiveness, namely human resources (Peterson and Zimmerman, 2004). Therefore, in the current turbulent environment, organizations have no choice but proper utilization of human resources as a competitive advantage (Schneider and McDonald, 2007). In fact, effectiveness associated with the performance and providing satisfaction for humans are among efforts conducted in this regard (Yukle, 2008). Organizational effectiveness is deeply embedded in the literature and it is considered as a major issue at all organizational analyses (Zheng, 2010). Organizations are dealing with many complex challenges and human resource management has significant positive impact on their success. Appropriate behavioral models of managers and director create strong incentive for staff. In addition, it would increase staff satisfaction leading to high efficiency in their work (Steinhardt, 2003).Organizational effectiveness is not a single concept, but it is a complex subject that includes different preferences and expectations (Katsikea, 2011). From Choo and Bowely perspective in 2007, when an organization plans lead to realization of its objectives, it means that organizational effectiveness has been confirmed. Organizational effectiveness is a situation in which the considered organization consumes resources at limited level and it is able to achieve its goals based on specified 
criteria (Wright, 2007). Staff satisfaction and estaff performance have been considered in this study based on their great efforts as the most important outcomes of staff effectiveness and they have been considered as some of the most important of organizational effectiveness by many researchers including Avolio and Bass (2004), Briggs (2008), and Duerr (2009). That is why we decided to study the relationship between empowerment and effectiveness of staff. Nowadays, it is difficult to imagine success of organization and and effectiveness of staff without plans and activities effective in managing human resources, since human resource management help organizations achieve effectiveness, so that (Schuler, 2000; Ivancevich, 2001) suggest that human resource management is at the forefront of organizational effectiveness. Using a technique to develop a sense of self-efficacy in staff can be effective in their empowerment (Pelit et al., 2011). Few studies support the positive effect of empowerment on performance of staff (Kirkman and Rosen, 1999; Spretzer, 1995; Spretzer et al., 1997) and staff satisfaction (Laschinger et al., 2001; Seibert et al., 2004). However, the literature shows that there is a noticeable lack of studies in the banking sector. Some of these studies include a study conducted by Saner and Eyupoglu in 2015, titled as "job satisfaction among staff of banks in Northern Cyprus aimed to provide empirical evidence to prove if there is job satisfaction among bank staff in North Cyprus" (Saner and Eyupoglu, 2015). The results of their study showed that bank staff is satisfied with their jobs. In a study conducted by Vogtlin et al in 2015 tilted as "how can we empower staff", they followed this hypothesis that training participation related to empowerment is correlated with increased power, effort, and independence of staff. The results showed a positive relationship between training participation and raising the psycho-social empowerment with different effects of empowerment dimensions (Voegtlin et al., 2015). Appropriate behavioral models of employees and directors create a strong incentive for staff. In addition, it would increase staff satisfaction leading to high efficiency in their work (EbrahimiMehrabani and Shajari, 2013). Due to lack of studies on the effects of empowerment dimensions on effectiveness of staff, especially in the banking sector and the importance of considering them in order to achieve organizational goals, it is necessary to conduct such studies. Therefore, we aim to find an 
answer for the question what is the impact of National Bank staff empowerment on their effectiveness.

\section{Literature review}

\section{Staff effectiveness}

Effectiveness is an issue proposed scientifically by Drucker, senior management experts, fifty years ago and several studies began in 1970s about it. In discussing the effectiveness of the organization, it should be noted that effectiveness and organizational goals are completely interlinked. In fact, in effectiveness practice, we see that achievement to organizational goals is considered (Teng, 2010). According to Daft in 1998, organizational effectiveness is extent to that organization approaches to its goals or objectives. This definition reflects that all organizations should determine how much they have made effort to achieve their organizational goals and how much they have achieved them. In other words, organizational effectiveness is the extent to which one organization has met its goals using specific resources, without wasting their resources, without wearing unnecessary members and its community (Yukle, 2008). In other words, the organizational effectiveness is extent or degree to which organizations achieve their goals (Hunter et al., 2007; Delong and Fahey, 2000; Bates and Rock, 2004; Sharma and Kaur, 2011). In general, calculation of effectiveness is not simple in an organization, and various methods and indices have been provided to measure and assess it (Daft, 2012; McMaster, 1996). Competence development improves the effectiveness of work time and increased work time effectiveness will improve other indices of organizational effectiveness. In fact, inner satisfaction, happiness and encouragement are productive of staff that is effective in efficiency and effectiveness in organization and guiding it to the highest possible productivity. Effective organization is one organization that is able to manage ambiguity, flexibility, customer-oriented, production, value-oriented, and structured learning, and can identify main area of employment and high empowerment of staff (Uhl-Bien et al., 2007).

\section{Staff empowerment}

The history first definition provided for empowerment backs to 1788 in which empowerment was considered as delegation of authority in its organization role that this authority should be 
given to an individual meaning enthusiasm of an individual to accept responsibility. It was a word interpreted for the first time as accountability formally (Wilkinson, 1993). Empowerment is inherent motivation of people to improve the potential (Sharon et al., 2013). In addition to individual empowerment, researchers increasingly have focused on the large number of interpretation on empowerment published by large number of studies in this area (for example, Chen et al., 2007; Kirkman et al., 2004; Mathieu et al., 2006). Empowerment is not division of a given amount of power, but rather it is a process in which power of every person increases by virtue of it. Empowerment is influence based on competency that must be created. This power is far beyond the power divided or shared. Empowerment is power resulted from the idea that power can and should be created through continuous improvement of competence and its application (Hao-Chieh and Nayel, 2014). Empowerment is a process through which managers allow staff to gain power and find a way within the organization (Cox et al., 2006). Empowerment and giving freedom to staff are essential strategies to increase performance and provide survival in today's organizations, because the vast environmental changes in today's rapidly changing environment makes flexibility of organizations to ensure their survival as essential (Sahin, 2007). Empowerment refers to the process in which the manager helps staff gain the ability to make independent decisions. This process is not only effective in performance of individuals, but also it I effective in their personality (Wang and Lee, 2009). The most important concept of empowerment is delegation of authority to the lowest levels of the organization. Decision-making process should have a high degree of focus and work groups or individuals should be responsible for an integral part of business processes. Empowerment means preparing staff who have enough independence and allowing them to solve unpredicted situations of a problem such a complaints (Gill et al., 2010). Empowerment is considered as the process of increasing the sense of self-efficiency in individuals through identification and removal of conditions disabled staff. In an article titled "The empowerment process: the unity of theory and practice", they consider empowerment as a motivational approach means being able (not delegating power). Being able refer to creation of conditions to increase the motivation to do given duties, through fostering a sense of personal self-efficacy (He et al., 2010). 


\section{MATERIAL AND METHODS}

Based on a literature review, conceptual model of study was presented, adapted from the model of EbrahimiMehrabani and Shajari (2013). In this study, we aim to find an appropriate answer to identify main problem of study that is the impact of National Bank staff empowerment on their performance.

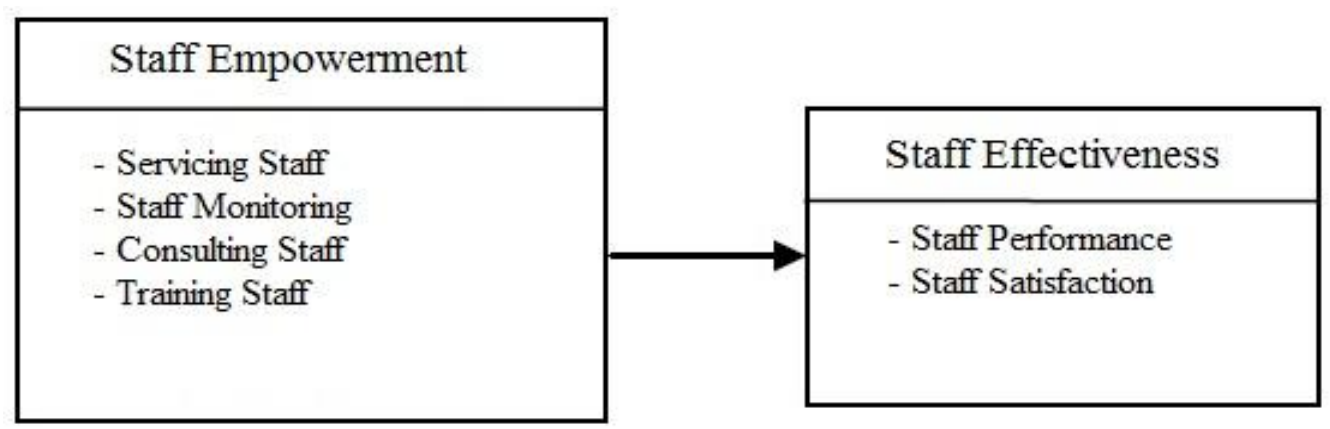

Fig.1. Conceptual model of study adapted from model of (EbrahimiMehrabani and Shajari,

2013)

According to model and literature provided, following hypotheses are presented:

\section{The main hypothesis}

H1: There is a positive relationship between staff empowerment and effectiveness of National

Bank staff in Guilan province.

\section{Sub-hypotheses}

H1a: There is a positive relationship between serving staff and performance of staff in National Bank branches of Guilan province.

H1b: There is a positive relationship between serving staff and satisfaction of staff in National Bank branches of Guilan province.

H1c: There is a positive relationship between monitoring on staff and performance of staff in National Bank branches of Guilan province.

H1d: There is a positive relationship between monitoring on staff and satisfaction of staff in National Bank branches of Guilan province.

H1e: There is a positive relationship between consulting staff and performance of staff in National Bank branches of Guilan province.

H1f: There is a positive relationship between consulting staff and satisfaction of staff in National Bank branches of Guilan province. 
H1g: There is a positive relationship between training staff and performance of staff in National Bank branches of Guilan province.

H1h: There is a positive relationship between training staff and satisfaction of staff in National Bank branches of Guilan province.

This study is applied in terms of data collection and it is survey type of descriptive study in terms of data collection. The study population includes staff of National Bank branches in Guilan province, that their number is 1397 people. Cochran formula was used to determine sample size of study and 302 people were selected as minimum sample of study sample. Simple random sampling was used as method of sampling. Fir increased confidence, 360 questionnaires were distributed that 315 questionnaires were returned and analyzed. Method of data collection is using questionnaire (see Appendix) that it was distributed among samples of study after that its validity and reliability were confirmed. SPSS software was used to analyze the data in descriptive statistics section and structural equation modeling using AMOS software was used in the inferential statistics using AMOS software to test the hypotheses of study. To confirm validity of questionnaire, confirmatory factor analysis (CFA) was used. the reliability of questions proposed to measure each variable using Cronbach's alpha coefficients is as shown in Table 1.

Table 1. Reliability table of questions related to variables

\begin{tabular}{|c|c|c|}
\hline Variable & Questions & $\begin{array}{c}\text { Initial alpha } \\
\text { coefficient }\end{array}$ \\
\hline Serving staff & $1-6$ & 0.88 \\
\hline Monitoring on staff & $7-9$ & 0.78 \\
\hline Consulting staff & $10-14$ & 0.89 \\
\hline Training staff & $15-19$ & 0.99 \\
\hline Empowering staff (19 items) & $1-19$ & 0.82 \\
\hline Staff performance & $20-22$ & 0.80 \\
\hline Staff satisfaction & $23-25$ & 0.84 \\
\hline Staff effectiveness & $20-25$ & 0.97 \\
\hline All items & $1-25$ & 0.85 \\
\hline
\end{tabular}


Cronbach's alpha coefficient was calculated for all variables higher than 0.7 . Therefore, present questionnaire is reliable. In order to test models, six important indices of fitness were used; one of these indices is significance index of Chi-square $(\mathrm{P})$ considered as one of the absolute fit indices. These indices are calculated based on the difference of variances and covariances observed on one hand and predicted covariances based on developed model parameters on other hand. Value higher than 0.05 indicates that Chi-square is significant. Normed Chi-square index (CMIN / DF) that its value between 1 to 5 and Root Mean Squared Error of Approximation that its value lower than 0.08 confirm the model are two other indices used in this study. These indices are considered among Parsimonious Fit Indices. These indices aim to compensate the most important weakness of absolute fit indices (improving the value of fit indices by adding parameter to model). They also examine if losing one degree of freedom in exchange for freeing one parameter for estimation leads to improvement of absolute fit indices or not. The other three indices that were used to model fit were incremental fit index (IFI), Tucker-Lewis Index (TLI) and the comparative fit index (CFI), which their vales higher than 0.9 represent that model is acceptable. These indices are considered as most important Comparative Fit Indices. Comparative Fit Indices to complete absolute fit indices compare the theoretical model and examine to find if $\mathrm{t}$ is statistically acceptable, weaker or had no difference with it, by assuming one or more model as base.

\section{RESULTS AND DISCUSSION}

In terms of gender in the study group, $79 \%$ of participants $(n=249)$ were male and $21 \%$ of participants $(n=66)$ were female. In terms of age, 12.4 percent of participants were 30 or under 30 years old, 36.2 percent of them were 30-40 years old, 49.5 percent of them were 40-50 years old, and 1.9 percent of them were older than 50 . In term of education, $1.0 \%$ of participants in the study group had associate degree, $30.8 \%$ of them had bachelor degree, 66.3 percent of them had master degree, and 1.9 percent of them had $\mathrm{PhD}$ degree. In terms of marital status in the studied group, $13 \%$ of participants were single and $87 \%$ of them were married. To determine how much indices are acceptable for measuring models, firstly, all measuring models should be analyzed separately. Based such approach, 4 measuring models 
for variable of empowerment (servicing staff, monitoring on staff, counseling staff, training staff) and two measuring models of staff effectiveness (staff performance, staff satisfaction) were tested separately.

Table 2. General fit indices of Structural equation modeling model analysis of research hypotheses

\begin{tabular}{|c|c|c|c|c|c|c|}
\hline Indices & P & CMIN/DF & IFI & TLI & CFI & RMSEA \\
\hline $\begin{array}{c}\text { Servicing staff- before } \\
\text { modification }\end{array}$ & 0.000 & 4.770 & 0.89 & 0.77 & 0.88 & 0.122 \\
\hline $\begin{array}{c}\text { Servicing staff- after } \\
\text { modification }\end{array}$ & 0.268 & 2.380 & 0.88 & 0.97 & 0.99 & 0.020 \\
\hline Monitoring on staff & 0.129 & 2.670 & 0.96 & 0.77 & 0.86 & 0.067 \\
\hline $\begin{array}{c}\text { Consulting staff-before } \\
\text { modification }\end{array}$ & 0.000 & 3.770 & 0.89 & 0.77 & 0.88 & 0.112 \\
\hline $\begin{array}{c}\text { Consulting staff-after } \\
\text { modification }\end{array}$ & 0.250 & 2.780 & 0.88 & 0.97 & 0.99 & 0.031 \\
\hline $\begin{array}{c}\text { training staff-before } \\
\text { modification }\end{array}$ & 0.002 & 1.045 & 0.76 & 0.76 & 0.76 & 0.032 \\
\hline training staff-after modification & 0.365 & 2.501 & 0.92 & 0.99 & 0.99 & 0.010 \\
\hline $\begin{array}{c}\text { empowerment-before } \\
\text { modification }\end{array}$ & 0.000 & 1.889 & 0.89 & 0.77 & 0.88 & 0.116 \\
\hline empowerment-after modification & 0.140 & 2.950 & 0.88 & 0.97 & 0.99 & 0.041 \\
\hline $\begin{array}{c}\text { Staff performance-before } \\
\text { modification }\end{array}$ & 0.000 & 3.890 & 0.89 & 1.05 & 0.96 & 0.115 \\
\hline $\begin{array}{c}\text { Staff performance-after } \\
\text { modification }\end{array}$ & 0.420 & 2.990 & 1.05 & 0.97 & 0.99 & 0.033 \\
\hline $\begin{array}{c}\text { Staff satisfaction-before } \\
\text { modification }\end{array}$ & 0.000 & 2.069 & 0.89 & 1.05 & 0.96 & 0.135 \\
\hline $\begin{array}{c}\text { Staff satisfaction-after } \\
\text { modification }\end{array}$ & 0.320 & 3.680 & 1.05 & 0.97 & 0.99 & 0.044 \\
\hline $\begin{array}{c}\text { Staff effectiveness-before } \\
\text { modification }\end{array}$ & 0.000 & 3.890 & 0.89 & 1.05 & 0.96 & 0.215 \\
\hline $\begin{array}{c}\text { Staff effectiveness-after } \\
\text { modification }\end{array}$ & 0.220 & 3.990 & 1.05 & 0.97 & 0.99 & 0.033 \\
\hline
\end{tabular}


Table 3. Regression coefficient (results of hypotheses testing)

\begin{tabular}{|c|c|c|c|c|c|c|c|c|c|}
\hline \multirow{3}{*}{$\begin{array}{c}\begin{array}{c}\text { Number } \\
\text { of } \\
\text { hypothe } \\
\text { sis }\end{array} \\
1\end{array}$} & \multicolumn{3}{|c|}{ hypothesis } & \multicolumn{3}{|c|}{ Regression coefficients } & \multirow{3}{*}{$\begin{array}{c}\text { Critical } \\
\text { value }\end{array}$} & \multirow{3}{*}{$\begin{array}{c}P \\
0.000\end{array}$} & \multirow{3}{*}{$\begin{array}{c}\text { Result } \\
\text { Confirmed }\end{array}$} \\
\hline & & & & \multirow{2}{*}{$\begin{array}{c}\begin{array}{c}\text { Direct } \\
\text { effect }\end{array} \\
0.60\end{array}$} & \multirow{2}{*}{$\begin{array}{c}\text { Indirect } \\
\text { effect }\end{array}$} & \multirow{2}{*}{\begin{tabular}{|l|}
$\begin{array}{l}\text { Total } \\
\text { effect }\end{array}$ \\
0.60
\end{tabular}} & & & \\
\hline & Servicing staff & $\rightarrow$ & $\begin{array}{c}\text { Staff } \\
\text { performance }\end{array}$ & & & & & & \\
\hline 2 & Servicing staff & $\rightarrow$ & $\begin{array}{c}\text { Staff } \\
\text { satisfaction }\end{array}$ & 0.80 & - & 0.80 & - & 0.000 & Confirmed \\
\hline 3 & $\begin{array}{l}\text { Monitoring on } \\
\text { staff }\end{array}$ & $\rightarrow$ & $\begin{array}{c}\text { Staff } \\
\text { performance }\end{array}$ & 0.59 & - & 0.59 & - & 0.000 & Confirmed \\
\hline 4 & $\begin{array}{l}\text { Monitoring on } \\
\text { staff }\end{array}$ & $\rightarrow$ & $\begin{array}{c}\text { Staff } \\
\text { satisfaction }\end{array}$ & 0.71 & - & 0.71 & - & 0.000 & Confirmed \\
\hline 5 & Consulting staff & $\rightarrow$ & $\begin{array}{c}\text { Staff } \\
\text { performance }\end{array}$ & 0.85 & - & 0.85 & - & 0.000 & Confirmed \\
\hline 6 & Consulting staff & $\rightarrow$ & $\begin{array}{c}\text { Staff } \\
\text { satisfaction }\end{array}$ & 0.80 & - & 0.80 & - & 0.000 & Confirmed \\
\hline 7 & training staff & $\rightarrow$ & $\begin{array}{c}\text { Staff } \\
\text { performance }\end{array}$ & 0.66 & - & 0.66 & - & 0.000 & Confirmed \\
\hline 8 & Training staff & $\rightarrow$ & $\begin{array}{c}\text { Staff } \\
\text { satisfaction }\end{array}$ & 0.59 & - & 0.59 & - & 0.000 & Confirmed \\
\hline $\begin{array}{l}\text { Main } \\
\text { hypothe } \\
\text { sis }\end{array}$ & $\begin{array}{c}\text { staff } \\
\text { Empowerment }\end{array}$ & $\rightarrow$ & $\begin{array}{c}\text { Staff } \\
\text { effectiveness }\end{array}$ & 0.75 & - & 0.75 & - & 0.000 & Confirmed \\
\hline
\end{tabular}

Standardized regression coefficient for the main hypothesis based on table (3) is 0.75 with a P value equal to 0.000 which is smaller than 0.05 . Therefore, it can be concluded that the hypothesis is accepted with 0.95 confidence level. In other words, it can be claimed that there is significant positive relationship between empowerment and effectiveness of staff in National Bank branches in Guilan province. Therefore, the main hypothesis is confirmed, and final structural equation model (SEM) is shown in Figure 2. 


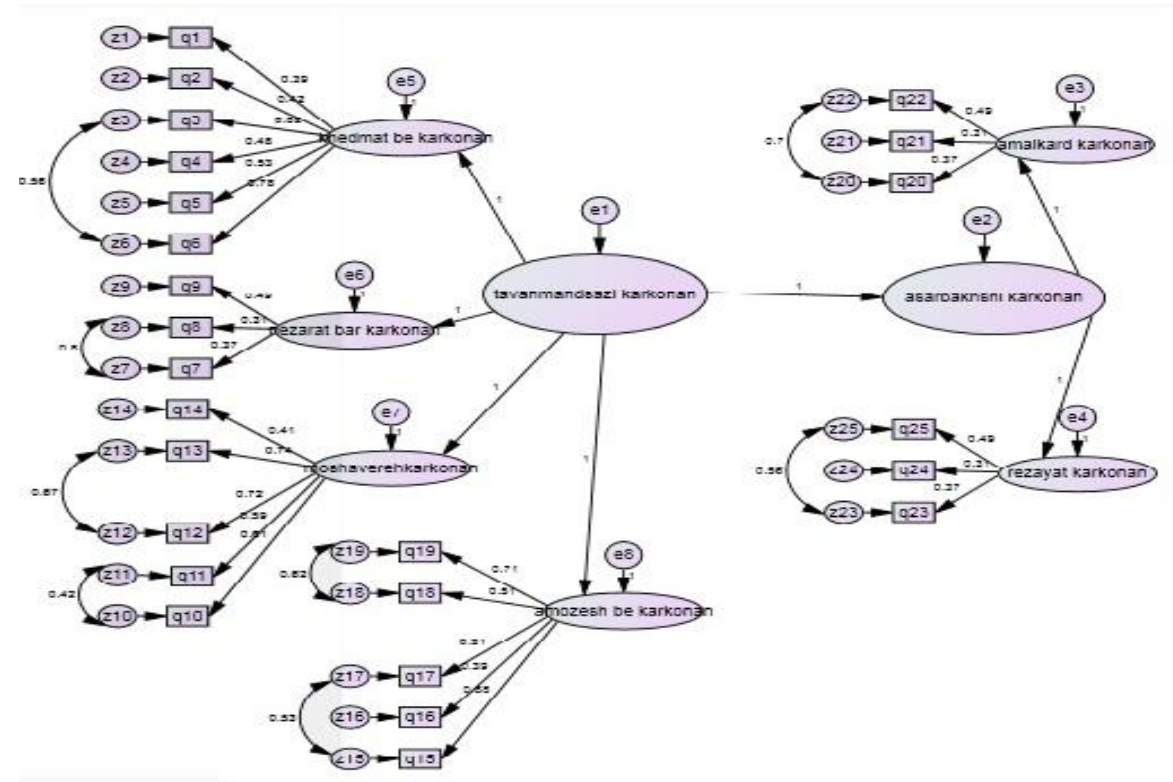

Fig.2. Final model of Structural equation used in this study

Empowerment of staff leads to increased sales and profits, reduced costs, increased efficiency, increased organizational commitment, resolving of the problems, and much coordination in the works. Sense of empowerment has a considerable impact on the performance of staff, as when people have sense of empowerment, it will lead to numerous individual and organizational interests such as creativity, flexibility, problem solving, quality job performance with high quality, job satisfaction, and health and mental health. In addition, empowered people are self-control and self-regulated. They readily accept responsibility, have positive attitudes about themselves and others, and see other as coworker and partner not rival. Therefore, considering literature and importance of empowerment, as one of the main indicator of human resources development, its impact on individual performance of staff in an organization can be seen easily (Chiang et al., 2014; Hamid et al., 2013). Good performance increases efficiency of organization leading to increased empowerment and effectiveness and improved national economy, finally. Psychological empowerment and job performance are two organizational variables having significant impact on organizational effectiveness and success of an organization and a society (Ning et al., 2009). According to the results of study, there is a significant relationship between staff empowerment and staff effectiveness in National Bank branches of Guilan province that these results are consistent with results of previous research conducted on the empowerment and effectiveness (Kirkman and Rosen, 
1999; Spretzer, 1995; Spretzer et al., 1997; EbrahimiMehrabani and Shajari, 2013). Considering the impact of servicing staff on their performance, it is recommended that bank to provide incentive mechanisms and distinctive service facilities to satisfy staff and better performance of them. Some of these mechanisms include providing more attractive working environment and avoiding monotony and granting conditions and facilities in accordance with staff performance. Additionally, due to lack of impact of monitoring role on performance and satisfaction of staff, it is suggested to instead of regulatory processes, conversation and encouragement space to be used. It is also recommended training to be used to improve the performance of staff. Additionally, due to the negative mentality towards monitoring, it is recommended that monitoring to be used with psychological and friendly methods and techniques in order to change the mentality and use of advantages of monitoring.

\section{REFERENCES}

[1] Avolio B, Bass B. 2004. Multifactor Leadership Questionnaire Sampler Set: Manual, Forms, and Scoring Key. Menlo Park, CA: Mind Garden.

[2] Briggs, DG. 2008. The Relationship between Leadership Practices and Organizational Effectiveness Outcomes: A Public Transit Agency Study. Doctoral Dissertation. Capella University

[3] Chiang, YH, Shih, HA, Hsu, CC. High commitment work system, transactive memory system, and new product performance. Journal of Business Research, 2014, 67(4):631-640.

[4] Choo S, Bowley C. Using training and development to affect job satisfaction within franchising. Journal Of Small Business And Enterprise Development, 2007, 14(2):339 - 352.

[5] Cox, A, Marchington, M., Sutter, J.Embedding the provision of information and consultation in the workplace: a longitudinal analysis of employee outcomes in 1998 and 2004, DTI Employee Relations Research Series, 2007, 72.

[6] Daft, RL. Organization Theory and Design, 6th ed., Southwestern College Publishing, Cincinnati, OH, 1998.

[7] Drucker P. 2006. The Effective Executive: The Definitive Guide to Getting the Right Things Done. New York: Collins. 
[8] Duerr, RA. 2009. Leadership Styles and Organizational Outcomes in Engineering Societies' Local Chapters. Capella University

[9] Ebrahimi M. Sh, Shajari, M.Knowledge Management Practices and Implementation of E-Insurance.International Conference on Informatics and Creative Multimedia (ICICM). International Conference on Informatics and Creative Multimedia, 2013: 186-190

[10] Gill, A, Fitzgerald, S, Bhutani, S, Mand, H. The relationship between transformational leadership and employee desire for empowerment. International Journal of Contemporary Hospitality Management, 2010, 22(2):263-73.

[11] Hamid SF, Nordin, N, Adnan, AA, Sirun, N.. A Study on Primary School Teachers' Organizational Commitment and Psychological Empowerment in the District of Klang.Procedia-Social and Behavioral Sciences, 2013, 90:782-787.

[12] Hao-Chieh, L, Nayel, R. 2014. CEO-TMT exchange, TMT personality composition, and decision quality: The mediating role of TMT psychological empowerment. The Leadership Quarterly 25:943-957

[13] He P, Murrmann SK, Perdue RR. An investigation of the relationships among employee empowerment, employee-perceived service quality, and employee job satisfaction in a US hospitality organization, Journal of Foodservice Business Research, 2010,13(1):36-50.

[14] Katsikea, E, Theodosiou, M, Perdikis, N, Kehagias, J. The effects of organizational structure and job characteristics on export sales managers' job satisfaction and organizational commitment. Journal of World Business, 2011, 46:221-223.

[15] Kirkman, B., Rosen, B. Beyond Self-Management: Antecedents and Consequences of Team Empowerment. Academy of Management Journal, 1999, 42(1):56-74.

[16] Laschinger H, Finegan J, Shamian J. The Impact of Workplace Empowerment and Organizational Trust on staff Nurses Work Satisfaction and Organizational Commitment. Health Care Management Review, 2001, 26:7-23.

[17] Ning, S, Zhong, H, Libo, w, Qiujie, L. The Impact of nurse Empowerment on Job Performance. Journal of Advanced . 
Pelit, E, Öztürk, Y, Arslantürk, Y. 2011. The Effects of Employee Empowerment on Employee Job Satisfaction: A Study on Hotels in Turkey. International Journal of Contemporary Hospitality Management, 2009, 23(6):784-802.

[18] Peterson NA, Zimmerman MA. Beyond the Individual: Toward a Nomological Network of Organizational Empowerment. American Journal of Community Psychology, 2004 34(1):129-148.

[19] Schneider B, McDonald SK. (Eds.). Scale-up in education: Vol. 1. Ideas in principle. Lanham, MD: Rowman\& Littlefield, 2007.

[20] Seibert, S, Silver, S, Randolph, W.. Taking Empowerment to the Next Level: A Multiple-Level Model of Empowerment, Performance, and Satisfaction, 2004.

[21] Sahin, N. PersonelGuc slendirmenin Is s TatminiveOrgutselBagl11ıUBes, YıldizlıOtel I $\mathrm{s}_{s}$ letmelerindeBirAras stırma, DokuzEylulUEnstitusu ,Izmir.zerineEtkisi: Dort veuniversitesiSosyalBilimler, 2007.

[22] Sharon I, Morowitz MJ, Thomas BC, Costello EK, Relman DA. Time series community genomics analysis reveals rapid shifts in bacterial species, strains, and phage during infant gut colonization. Genome Res, 2013, 23: 111-120.

[23] Spreitzer, G, Kizilos, MA, Nason, S.A dimensional analysis of the relationship between psychological empowerment and effectiveness, satisfaction and strain. Journal of Management, 1997, 23(5):679-704

[24] Spreitzer, G. Psychological Empowerment in the Workplace: Dimensions, Measurement and Validation.Academy of Management Journal, 1995, 38 :1442-1456.

[25] Tseng CC. The Effects of Learning Organization Practices on Organizational Commitment and Effectiveness for Small and MediumSized Enterprises in Taiwan.Unpublished Doctoral Thesis.Minnesota University, 2010

[26] Uhl-Bien, M, Marion, R, McKelvey, B.. Complexity leadership theory: Shifting leadership from the industrial age to the knowledge age. Leadership Quarterly, 2007, 18:298-318. 
[27] Voegtlin, C, Boehm, S, Bruch, H.. How to Empower Employees: Using Training to Enhance Work Units' Collective Empowerment. International Journal of Manpower, 2015, 36(3): $354-373$.

[28] Wang, G, Lee, P.D. Psychological empowerment and job satisfaction: an analysis of interactive effects. Group Organization Management, 2009, 34(3): 271-96.

[29] Wright PJ. Effective Leadership: An Analysis of the Relationship Between Transformational Leadership and Organizational Climate. Capella University. Miami, 2007. [30] Yukle G. How Leaders Influence Organizational Effectiveness. The Leadership Quarterly, 2008, 19 (6):708-723.

[31] Zheng w, yang B, Mclean GN. linking organizational culture ,structure ,strategy, and organizational effectiveness:Mediating role of knowledgemanagement. journal of Business Research, 2010, 63:764.

\section{How to cite this article:}

Louyeh A A, Ebrahimi P, Soleimani A G, Shadmehr A. The relationship between empowerment and effectiveness of staff (case study: national bank staff in guilan province). J. Fundam. Appl. Sci., 2016, 8(2S), 1272-1286. 